\title{
A Qualitative Study on the Best Motivational Teaching Strategies in the Context of Oman: Perspectives of EFL Teachers
}

\author{
Mohamad Yahya Abdullah ${ }^{1,2}$, Hawa Mubarak Harib Al Ghafri ${ }^{1} \&$ Khadija Saleem Hamdan Al Yahyai ${ }^{1}$ \\ ${ }^{1}$ English Department, Buraimi Univeristy College, AL Buraimi, Sultanate of Oman \\ ${ }^{2}$ Universiti Kebangsaan Malaysia, Selangor, Malaysia \\ Correspondence: Mohamad Yahya Abdullah, English Department, Buraimi Univeristy College, AL Buraimi, \\ Sultanate of Oman.
}

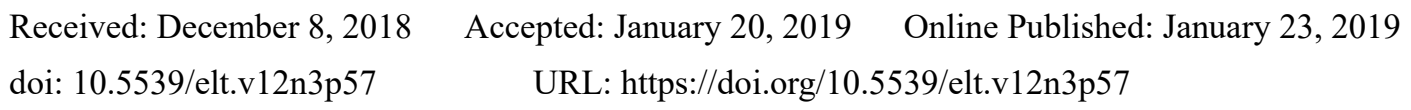

\begin{abstract}
In the pedagogical process, lack of motivation becomes a controversial issue. In this qualitative study, the researcher intended to explore the best motivational teaching strategies from the perspectives of the EFL teachers at Buraimi University College (henceforth BUC) in Oman. Purposeful sampling was used in the selection of five EFL teachers in English language department at BUC. The protocol of interview (semi-structured interviews) was conducted for data collection. The obtained data provided by the participants was analysed using qualitative thematic analysis to answer the questions and accomplish the objective of the present study. The findings revealed that motivational strategies would not be applicable in any classroom without creating a helpful, interactive, engaging, and enjoyable environment. The participants of the current study believe in the vital role of playing games in stimulating the interest and enthusiasm of learners as well as giving fun and energetic environment. Besides, it is essential to inspire students with the feelings of a sense of accomplishment through helping them to set realistic goals according to their learning abilities and observe their progress once in a while. However, in any learning environment developing motivation is a difficult task for the teachers because students learn differently and every student is diverse in her way.
\end{abstract}

Keywords: motivational teaching strategies, classroom environment, playing games, EFL teachers

\section{Introduction}

In Oman society, English received its popularity many years ago due to globalisation. It has become a vital element in meetings, technology, tourism, business, and commerce (Al-Mahrooqi, 2012; Hussin, 2015; Challob, 2016; Abdullah et al., 2018). The increase of practising English in the Omani society has a significant impact in promoting effective communication and eliminating language boundaries. Therefore, the government in Oman encourages the Ministry of Education to take responsibility for providing students with functional plans and strategies to learn the English language (Al-Issa \& Al-Bulushi, 2012). Since then, the ministry of education (1996) has clearly stated that basic education aims to make the learner gain the necessary skills for life by developing the ability to learn EFL (Al-Abri, 2008). It is clear that learning English becomes one of the priorities of education in Oman many decades ago. Although the remarkable efforts made to improve the learning of English in Oman, there are many difficulties which still hinder the progression of English language learning.

According to AL-Zedjali (2009), the classroom is the only place where many Omanis can use English. Therefore, Omani people lack the motivation to learn English since they do not have authentic opportunities to practice the target language outside the classroom. AL-Issa (2010) has also added that the Omani students are unable to attain the level of motivation which required for fruitful learning of English language. On the other hand, learning a foreign language inside the classroom has always been one of the argumentative issues that occurred between the teacher and his/her students. Teachers are often getting upset with those students who are not motivated, and they consider them as being not interested in learning English. Lack of motivation element means there is insufficient energy source required to drive students to successfully deal with their environment through active learning (Tohidi \& Jabbari, 2012).

Moreover, this issue can have numerous reasons that push some students to be incurious such as teachers' attitude and style of learning. The negative attitude of the teacher toward some students is mostly associated with 
low students 'performance (Brewer \& Burgess, 2005). Another reason can be the material and strategies used in learning. For example, the findings of a study conducted by Stutz, Schaffner, and Schiefele (2016) showed that giving the students books and texts that match their interest will strongly increase their motivation to learn. Therefore, the student will have the desire to understand the text by asking questions and interacting with the teacher. Thus, the instructors should be selective about the materials they use in teaching English.

\section{The Rationale for the Present Study}

In the pedagogical process, lack of motivation becomes a controversial issue. A student who is bored or inattentive, or who has no goal and desire to learn is unlikely to take advantage of the educational programs, regardless of its effectiveness. From a different point of view, some students do not work effectively in the classroom because they have difficulty in adapting to the new social context, especially in colleges with a new environment. In Oman, the dominant language of teaching in higher education is English, and most of the teaching staff are foreigners. However, EFL learners generally cannot use English effectively in communication as they are required to have (Al-Issa, 2005). As a result, Omani EFL students faced difficulties to communicate with their teachers using the target language. Across Oman, it is unsurprising that a considerable number of students are perceived as being uninterested or not motivated to learn English. Thus, it is essential to focus sufficiently on what motivates the student in college.

According to the ample literature about learning motivation, there are various strategies that the instructor can adopt in order to help English learner to form positive motivation to learn English. Some of these techniques can be employed to motivate students positively. This will not only acknowledge them about their lifestyle but also bring curiosity to know more about the new things.

From teacher's perspective, this study aims to shed the lights on the best motivational teaching strategies that promote students to learn English and lead to improve their language competencies. Moreover, it highlights the expected challenges which might encounter teachers while applying these strategies.

\section{Review of Literature}

\subsection{Theoretical Framework}

The field of second language learning can be old and new at the same time. It is old as in researcher for centuries have been fascinated by the inquiring postured of nature of the target Language, and language teaching. However, it is new in the sense that filed is currently represented only by goes back 40-50 year (Richards, 2010).

The effective filter is one of Krashen's five hypothesizes of Second Language Acquisition (SLA). The five hypotheses are the input hypothesis, the acquisition-learning hypothesis, the monitor hypothesis, the natural order hypothesis and effective filter hypothesis (Zafar, 2009). The affective filter hypothesis had first suggested in 1977. It proposes to provide a positive feeling environment and to discuss interesting topics that would encourage the student to work harder (Du, 2009). Besides, Krashen (1981) postulates three effective variables filter in learning: motivation, self- confidence, and anxiety.

\subsection{Motivation}

Most researchers and instructors would agree that motivation is one of the most important factors in language learning (Krashen, 2009). Without motivation, it would be difficult to achieve long-term goals, whatever the educational program and whoever the educator. Regarding the meaning of motivation, Gardner (2007) has defined motivation learners' willingness to learn the second dialect due to their tenancies and satisfaction experience to do activities. So, the motivation in English language learning process refers to the desire and impetus of acquires. With regarded of foreign language acquisition, the scholars usually distinguished between the two best classifications for motivation are called intrinsic and extrinsic motivation. The differences between them were made up by Dci and Ryan (2000). They demonstrated that little motivation might start from internal or external the student.

\section{A. Intrinsic Motivation}

First of all, intrinsic motivation identified with an internal wish to accomplish something. Dci (1975) defined intrinsically motivated activities as "the ones for which there's no obvious reward except the action itself" (p. 23). Self -assurance hypothesis puts emphasis on three natural mental needs which should be fulfilled all together for person intrinsically motivated. These requirements are:

1) Independence, in choosing what to do, and how to do it.

2) Competence, capacities, and abilities by which we figure out how to control our environment. 
3) Relatedness, the relationship we create through our association with others.

This assumption has a huge implication for students possessed with this learning procedure. To be specific, students will probably experience intrinsic motivation in an environment that advanced the fulfilment of these requirements than in the one which dismisses them (Brophy 2014). Additionally, as indicated by a few investigations, intrinsically motivated learning has a tendency to be more profitable than the extrinsically oriented one (Dci\& Ryan, 2000).

\section{B. Extrinsic Motivation}

On the other hand, the individuals who are extrinsically motivated are played out a specific activity not because they truly enjoy it, but because of reward that is accessible in their environment (Topalov, 2011). The extrinsic objective can differ from short-term goals (decent evaluations, prizes from educator and parents, participating in a competition, etc to long-term ones (probability of winning a scholarship, better openings for work, etc). Certain investigation completed in the 1980s demonstrated that rewards could lead to a decrease in intrinsic motivation among individuals who are already doing cretin things because of their own purpose (Brophy, 2004).

Despite the fact that the qualification between those two sorts of motivation is still essential while we are talking about motivation, the attitude towards extrinsic motivation has changed. Today, it is believed that intrinsic motivation and extrinsic reward-motivated learning (Topalov, 2011; Abdullah \& Al-Mofti, 2017).

As a result, it is essential to look at the build of motivation, not as a single element but rather as a multi-functional one. The effective filter is believed to assume an important part in getting L2 understandable information. It may not be used by the L2 procure if there is no "mind block". Furthermore the successful filter act barrier to acquisition. Besides, the filter is up when the acquirer is unmotivated, lacking confidence (Krashen, 2009).

\subsection{Past Studies}

Undoubtedly, motivation is essential in the light of the fact of our lives; we have all seen the motivated person outperform the less motivated person in the execution of the class activity and outcome, despite the fact both of them have a similar capability (Woldkowsk \& Ginsberg, 2017). When learning a second or foreign language, the learner is not only acquiring second linguistic rule but also using some rules together with specific strategies to professionally learning a foreign language. Motivation in Learning is one of the most researched areas in EFL learning. In the whole world, the issue of L2 acquisition received much attention. So, Hundreds of the study about L2 learning and motivations have been conducted.

Dronyei and Ushioda (2013) came up with three classifications of values identified with L2; it consists of an intrinsic value, which deals with the inner interests of learners in L2; integrative value that deals with the positive attitude of learners towards the way of life and community of L2; and instrumental values, deal with the learning for occupation and duty, educational opportunities. The motivational strategy advances the instrumental values of learners. There are some suggested strategies which promote this value; it is very useful and enjoyable in motivating learner in L2 learning procedure.

Benson in (2013) supported the idea of a learner's self-efficiency in the education of foreign or second language. In this study they have mentioned three different approaches in order to enhance student motivation in EFL learning, they are:

a. Resource-Based Approach which deals with the independent utilisation of learning materials via self-sufficient students.

b. Technology-Based Approach which deals with the independent collaboration of students with the technologies of education.

c. Learner-Based Approach that deals with the improvement of students' abilities.

These aforementioned approaches intended to get change instructor and students on educational curriculum. The results of the current studies illustrated that learners are familiar with this motivational technique to empower their motivation for EFL learning. Additionally, the finding concluded that learners of a foreign language are much helpful; they become aware of the significance of L2 since it would be very effective in their future.

In the same sense, another interesting study which discussed the same motivation techniques suggested by Kakar and Pathan in (2017), EFL instructor revealed that for enhancing the motivation of EFL learners, they employed to promote learners with self-sufficiency motivational strategy. Likewise, they found it promotes learners' autonomy is very influential in their learning procedure in which they investigated the motivational outcome of the informative style of a language instructor. Moreover, the findings of this study illustrated that teachers were 
strongly supported learners' independence and the feedback which they were providing to learner's autonomy. Also, the result of present study illustrated that learner with high autonomy could be able to increase their level of understanding to achieve the assigned task by their instructors; the instructors familiarise students with the advantages of L2 learning.

In the last two decades, technologies have become an essential factor in the pedagogical process. In a study conducted by Al-Shawi (2014), the researcher examined the application of games as an effective learning strategy to obtain new English vocabulary, to make the learning procedure more attractive and enjoyable. The outcome of using this strategy showed an increase in the students' ability and their motivation to memorise new words effectively. Also, utilising games to practice students improve their vocabularies. Furthermore, Games provide logical contribution and allow the learners to interact effectively with peers, it allowing students to simplify the meanings of the words. This method also provided a challenge where they need their concentration to get a fruitful outcome from the various tasks which strengthens students' mental work and ability.

However, using games will contribute to making the teaching process more challengeable. However, after using games to teach vocabulary, it can be said that teachers can vary hisher methods of teaching. Thus, it is recommended that teachers should try using vocabulary games as well as the drilling method. All in all, this study recommend that teachers should consider recycling words regularly through using of drills to encourage student interaction as well as improve their motivation. Furthermore, and according to Raja (2017), due to the cooperative language learning strategy that used in a teaching session would enhance the learning of EFL. This technique has been demonstrated positive impact. Teaching session has found effective improvement of student's performance in reading as well as the other English language skills.

Although the body of literature contained a good number of past studies about the motivational teaching strategies, in the context of Oman, a few numbers of studies were conducted to investigate teaching techniques that might motivate students. In this qualitative study, the researcher intended to explore the best motivational teaching strategies from the perspective of the EFL teachers at Buraimi University College in Oman.

\section{Method}

In the current study, the researchers employed the qualitative research design to highlight the best motivational strategies which promote students to learn English language and the challenges that teachers might encounter while they are applying these strategies. This research paper used the purposive sampling technique to select five EFL teachers in English language department at BUC. The participants' age range was from 40 to 61 years old and had at least 15 years of teaching experience. For data collection, the one-on-one protocol of interview (semi-structured interviews) was conducted with this group of five professionals.

The obtained data provided by the participants was analysed using qualitative thematic analysis to answer the questions and accomplish the objective of the present study. To manage the data, all the responses about the motivational strategies and the challenges were categorized into common themes. In the current study, eight themes were emerged to addressed issues related to the central phenomena under investigation, six themes for the investigation about the motivational strategies and two themes about the challenges.

\section{Results}

Research Question One "What are the best motivational strategies which motivate EFL learners inside the classroom?"

\section{A. Vary in Teaching Methods}

Participants' responses showed a clear consensus that teacher must be inventive and adaptable. They reported that lecturers are still adopting traditional ways of teaching. They advocated to let the class be a new or another experience, for instance keeping away from routines. The lecturer can consolidate academic activities that get students to participate in the class effectively and consider more input through utilising collaborative learning, use of technology, classroom discussion, presentations, and group work. So, along these lines, each one of those will provide greater cooperation and the opportunity for students to gain new skills and knowledge. The participants of this study suggested some methods which from their point of views could enhance the process of language learning. They agreed that games and utilising group work activities play a vital role in developing different language skills and sustaining learners' language abilities.

\section{1) Games}

According to their responses, playing games can be considered as a useful and practical way in language learning. This strategy can improve the motivation level in learning because different games stimulate the interest and 
enthusiasm of the learners. Moreover, it gives a fun and playful environment that enhance a student's motivation and learning outcomes as well. The learners become more involved in all activities, and as a result, they learn more.

\section{2) Utilise group work effectively}

Another agreement was about working in groups which can be as a significant motivator. However, it is essential to ensure that working in groups provides a positive experience for all participants. It is too simple for one or few learners to be members and feel 'left out.' Even in groups, it might be a plan to pair learners who get on well with each other. Group work should also be closely observed, and an assessment should be carried out to observe learners' progress from time to time.

\section{B. Interesting task and relevance to students needs}

Instructors can help learners by observing the significance of their various interests, needs, and their reasons stand behind learning English which brings students to the classroom. Instructors need to have careful selection and tuning of the program and its materials. Additionally, the teacher should try to state learners' interests which could motivate and stimulate their desires to learn and seek more knowledge.

Furthermore, using different forms of learning materials is widely provoking their motivation and providing them with different types of material sources. Finally, regarding the ability differences among the learners, the lecturer should not make the task too easy or too challenging, it should be balanced between them. The role of applicable tasks helps to motivate students to recognise patterns and get new information.

\section{Setting realistic goals}

The teacher should help the learners to set realistic goals and make them recognise that each of them is different and has different learning capabilities. Setting goals realistically make learners feel a sense of accomplishment. Hence, when the goal is completed the learner will have immense self-satisfaction.

\section{Provide effective feedback}

All the participants advocated the positive role of teacher's and peers' feedback. They reported that feedback in the learning process gives learners the direction of their needs to reach their goals. In this sense, feedback sends a message to the students that the instructor cares about them. It also allows learners to become more involved in the classroom.

Moreover, feedback can inform students about their level of progress and their learning capabilities. It is essential to recognize and acknowledge any accomplishments- regardless of how small they may seem to others. Inside the classroom, learners generally need feedback to know about their capabilities to develop and keep-up their self-belief.

\section{E. Classroom environment}

Participants' responses showed the importance of creating helpful, interactive, engaged, and enjoyable environment in the classroom. This type of learning environment motivates students to work harder. Designing classroom activities and tasks should be done carefully to ensure encouraging environment. The factors of fun and playing games should be the main pillars of the process of this designing. When students have fun, they will pay great attention and focus more on their work and to get rid of boring lecturing routines. Indeed, in learning environment developing motivation is a difficult task for the teacher because students learn differently and every student is diverse in their way.

Research Question Two "What are the expected challenges which might encounter teachers during the application of these motivational strategies?"

It is crucial to identify the difficulties which might be faced by the teachers while applying the aforementioned motivational strategies. Although cooperative learning has been used inside the classroom, there are no strategies without drawbacks. Collaborative learning activities is not always an effective method especially with a large number of students. It seems to be the most apparent obstacle in the classroom.

Moreover, because of the class crowded, there might be some excessive noise. Most of the students will not have enough time to practice their target language sufficiently or overcome the L2 learning difficulties. Therefore, there will be a limited number of opportunities for exercising and frequently could not have the chance of learning English properly.

On the other hand, some lecturers are worried about having learners with different abilities in the same classroom. Individual differences would be troublesome for the teacher to implement the plan of lectures. Hence, 
the lecturer will need to vary his methods of teaching according to the individual differences and to care about how to deal with every student similarly.

\section{Discussion and Conclusion}

Without a doubt, motivation plays a crucial role in the language teaching process. It is essential to achieve long-term goals in different educational programs. Teachers define motivation as "the fundamental inner energy and enthusiasm which is essential to sustain and manage the language teaching process" (Ölmezer Öztürk, 2015, p. 1445). Moreover, Gardner (2007) illustrated that theory had defined motivation as "the degree to which individual works or strives to learn the second dialect due to a desire to do so and the satisfaction experienced in these activities". We have all seen that the motivated persons outperform the less motivated persons in the execution of the class activity and outcome, despite the fact both of them have a similar capability (Woldkowsk \& Ginsberg, 2017). The findings of this study revealed that it is essential to consolidate academic activities that get students to effectively participate in the class and consider more input through utilising collaborative learning, use of technology, classroom discussion, presentations, and group work. Therefore, the respondents of the current study suggest utilizing different techniques of teaching which can boost the process of language learning. Similarly, Al-Sharief (2013) suggested emphasizing the crucial role of integrating motivational strategies in any method of EFL classroom teaching.

Firstly, they suggested playing games to improve learners' motivation level because of games' role in stimulating the interest and enthusiasm of the learners as well as giving a fun and energetic environment. In this sense, Wouters et al. (2013) found that students learned more with utilising serious games integrated with other instruction methods. Secondly, the participants of this study reported working in groups can be a significant motivator. However, it is important to ensure their role in providing a positive experience for all participants and to observe learners' progress once in a while. Thirdly, teachers should try to state learners' interests which could motivate and stimulate their desires to learn and seek more knowledge. Certainly, using a diversity of learning materials is widely recommended to increase their motivation and to provide them with different types of material sources. Fourthly, the results showed the importance of inspiring learners with the feelings of a sense of accomplishment through helping them to set realistic goals according to their learning abilities. These results are the consensus with Rader (2005) who stated that students should write their goals to be able to reflect upon why they should attain their goals. Likewise, the results of the study conducted by Jahedizadeh et al. (2016) showed the positive effect of mastery goal orientation on the learners' achievement. Fifthly, teacher's and peers' feedback were one of the motivational strategies that have been advocated by the participants to be effectively used in the classroom. In their responses, they considered the feedback in the learning process gives learners the direction of their needs to reach their goals and can inform students about their level of progress and their learning capabilities. Thus, it is essential to recognise and acknowledge any accomplishments- regardless of how small they may seem to others. Finally, all these aforementioned motivational strategies will not be applicable in any classroom without creating a helpful, interactive, engaging, and enjoyable environment.

Nevertheless, having a significant number of students and having learners with different abilities might hinder the procedures for utilising the aforementioned motivational strategies. This seems to be the most apparent obstacle in the classroom. Therefore, teachers need to invest the time of the classroom through merging technology in their classes. Flipped learning can be adapted to maximise the time of learning. According to Wang (2016), English learning motivation can be cultivated by integrating technology which has a great significance to the field of college English education. Besides, it is essential to vary the methods of teaching according to the individual differences and to care about how to deal with every student similarly.

Accordingly, classroom activities and tasks should be designed carefully to ensure the encouraging environment. The factors of fun and playing games should be the main pillars of the process of this designing. When students have fun, they will pay great attention and focus more on their work and to get rid of boring lecturing routines. Indeed, in any learning environment developing motivation is a difficult task for the teacher because students learn differently and every student is diverse in her way.

Finally, the findings of this study showed in-depth understanding of the best motivational teaching strategies by the EFL teachers in the Omani context. The findings of the current study can be employed to develop the teaching practice in Oman. It is essential to study these issues to increase teachers' knowledge and skills to develop their teaching strategies effectively and to avoid using the least effective ones. Consequently, it would be meaningful if teachers utilise the aforementioned strategies in their classroom. They can help them to attract their learners' attention to learn the target language and increase their motivation. However, they should consider the differences among learners and hence different strategies affect differently with various type of learners. 


\section{Limitations}

Despite the limitation of having a sample number of participants that was specific to one group of five EFL teachers at BUC, the use of in-depth semi-structured interviews helps the researchers to elicit participants views about the best motivational teaching strategies. According to Turner III (2010, p. 695), "interviews provide in-depth information about participants' experiences and viewpoints of a particular topic." Although the results may not be generalised to populations in other locations and cultures outside Oman, this study is still useful for establishing a better understanding of the motivation strategies from the perspectives of EFL teachers. Therefore, it is hoped that this study can provide a good comprehension for the best motivational strategies in English language teaching.

\section{References}

Abdullah, M. Y., \& Al-Mofti, K. W. H. (2017). The impact of social support on EFL learners' motivation at Iraqi Kurdistan universities. Modern Applied Science, 11(7), 51. https://doi.org/10.5539/mas.v11n7p51

Abdullah, M. Y., Hussin, S., \& Shakir, M. (2018). The effect of peers' and teacher's e-feedback on writing anxiety 1 evel through CMC applications. International Journal of Emerging Technologies in Learning (iJET), 13(11), 196-207. https://doi.org/10.3991/ijet.v13i11.8448

Al-Abri, K. M. (2008). Teachers' Evaluation of EFL Textbooks Used in the Omani Basic Education Schools. (PhD Dissertation, Sultan Qaboos University).

Al-Issa, A. S. (2005). The implications of the teacher educator's ideological role for the English language teaching system in Oman. Teaching Education, 16(4), 337-348. https://doi.org/10.1080/ 10476210500345656

Al-Issa, A. (2010). ELT transformations in Oman: A critical perspective. In TESOL Arabia Conference, Zayed University, Dubai, United Arab Emirates.

Al-Issa, A. S., \& Al-Bulushi, A. H. (2012). English language teaching reform in Sultanate of Oman: The case of theory and practice disparity. Educational Research for Policy and Practice, 11(2), 141-176. https://doi.org/10.1007/s10671-011-9110-0

Al-Mahrooqi, R. (2012). English Communication Skills : How Are They Taught at Schools and Universities in Oman? English Language Teaching, 5(4), 124-130. https://doi.org/10.5539/elt.v5n4p124

Al-Sharief, S. (2013). The interplay of motivation and demotivation: The case of EFL learners majoring in English. International Journal of Applied Linguistics and English Literature, 2(1), 53-59. https://doi.org/10.7575/ijalel.v.2n.1p.53

Al-Shawi, M. (2014). Using Game Strategy for Motivating Students to Learn New English Vocabulary. Journal of American Arabic Academy for Sciences and Technology, 5(12), 137-146. https://doi.org/ $10.12816 / 0015403$

Al-Zedjali, K. A., \& Region, M. (2009). 12 Student's Beliefs' about Learning to Speak English. Retrieved from http://www.moe.gov.om/Portal/sitebuilder/Sites/EPS/Arabic/IPS/Importa/tesol/6/Student\%E2\%80\%99s\%20 beliefs\%20about\%20learning\%20to\%20speak\%20English.pdf

Brewer, E. W., \& Burgess, D. N. (2005). Professor's role in motivating students to attend class. Journal of STEM Teacher Education, 42(3), 3.

Brophy, J. (2013). Motivating students to learn. Routledge. https://doi.org/10.4324/9780203858318

Challob, A. A. I., Bakar, N. A., \& Latif, H. (2016). Collaborative blended learning writing environment: Effects on EFL students' writing apprehension and writing performance. English Language Teaching, 9(6), 229. https://doi.org/10.5539/elt.v9n6p229

Deci, E. (1975). Intrinsic Motivation. New York: Plenum Press. https://doi.org/10.1007/978-1-4613-4446-9

Dörnyei, Z., \& Ushioda, E. (2013). Teaching and researching: Motivation. Routledge.

Du, X. (2009). The Affective Filter in Second Language Teaching. Asian Social Science, 5(8), 162-165. https://doi.org/10.5539/ass.v5n8p162

Gardner, R. C., \& Lambert, W. E. (1959). Motivational variables in second-language acquisition. Canadian Journal of Psychology/Revue canadienne de psychologie, 13(4), 266. https://doi.org/10.1037/h0083787

Jahedizadeh, S., Ghanizadeh, A., \& Ghonsooly, B. (2016). The role of EFL learners' demotivation, perceptions of classroom activities, and mastery goal in predicting their language achievement and burnout. 
Asian-Pacific Journal of Second and Foreign Language Education, 1(1), 16. https://doi.org/10.1186/ s40862-016-0021-8

Kakar, S. K., \& Pathan, Z. H. (2017). Exploring the Motivational Strategies Practiced by Pakistani EFL Teachers to Motivate Students in Learning English Language. International Journal of English Linguistics, 7(2), 117-123. https://doi.org/10.5539/ijel.v7n2p117

Krashen, S. (1981). Second Language Acquisition and second language learning. Oxford: Pergamon Press.

Krashen, S. (2009). The comprehension hypothesis extended. Input Matters in SLA. Clevedon: Multilingual Matters, 81-94.

Hussin, S., Abdullah, M. Y., Ismail, N., \& Yoke, S. K. (2015). The effects of CMC applications on ESL writing anxiety among postgraduate students. English Language Teaching, 8(9), 167. https://doi.org/10.5539/ elt.v8n9p167

Oletić, A., \& Ilić, N. (2014). Intrinsic and extrinsic motivation for learning English as a foreign language. ELTA Journal, 2(2), 23-38.

Ölmezer Öztürk, E. (2015). A qualitative study on the motivation of Turkish EFL teachers working at state universities. Journal of Theory and Practice in Education, 11(4), 1437-1453.

Rader, L. A. (2005). Goal setting for students and teachers: Six steps to success. The Clearing House, January-February, 2005, 123-126. https://doi.org/10.3200/TCHS.78.3.123-126

Raja, M. S. H., Rehman Qureshi, A. S. A., \& Albesher, K. B. (2017). Application of Cooperative Learning Strategies (CLS) for Students' Focused Teaching (SFT) in EFL Class: An Experimental Study in the Summer Remedial Course for Adult Learners. Journal of Language Teaching \& Research, 8(2), 237-252. https://doi.org/10.17507/j1tr.0802.05

Richards, J. C. (2010). Competence and performance in language teaching. RELC Journal, 41(2), 101-122. https://doi.org/10.1177/0033688210372953

Ryan, R. M., \& Deci, E. L. (2000). Intrinsic and Extrinsic Motivations: Classic Definitions and New Directions. Contemporary Educational Psychology, 25(1), 54-67. https://doi.org/10.1006/ceps.1999.1020

Stutz, F., Schaffner, E., \& Schiefele, U. (2016). Relations among reading motivation, reading amount, and reading comprehension in the early elementary grades. Learning and Individual Differences, 45, 101-113. https://doi.org/10.1016/j.lindif.2015.11.022

Tohidi, H., \& Jabbari, M. M. (2012). The effects of motivation in education. Procedia-Social and Behavioral Sciences, 31, 820-824. https://doi.org/10.1016/j.sbspro.2011.12.148

Turner III, D. W. (2010). Qualitative interview design: A practical guide for novice investigators. The Qualitative Report, 15(3), 754-760.

Wang, K. (2016, July). Application of information technology in cultivating college English learning motivation. In Logistics, Informatics and Service Sciences (LISS), 2016 International Conference on (pp. 1-5). IEEE. https://doi.org/10.1109/LISS.2016.7854516

Wlodkowski, R. J., \& Ginsberg, M. B. (2017). Enhancing adult motivation to learn: A comprehensive guide for teaching all adults. John Wiley \& Sons.

Wouters, P., Van Nimwegen, C., Van Oostendorp, H., \& Van Der Spek, E. D. (2013). A meta-analysis of the cognitive and motivational effects of serious games. Journal of Educational Psychology, 105(2), 249. https://doi.org/10.1037/a0031311

Zafar, M. (2009). Monitoring the "Monitor": A Critique of Krashen's Five Hypotheses. The Dhaka University Journal of Linguistics, 2(24), 139-146.

\section{Copyrights}

Copyright for this article is retained by the author(s), with first publication rights granted to the journal.

This is an open-access article distributed under the terms and conditions of the Creative Commons Attribution license (http://creativecommons.org/licenses/by/4.0/). 